\title{
Analysis of Trends in Taxation and Foreign Economic Operations with Cereal Products in Ukraine
}

\author{
Natalie Yuriivna Shevchenko \\ Department of Finance, National University of Life and Environmental Sciences of Ukraine, Kyiv, Ukraine \\ Email address: \\ 200582_@ukr.net \\ To cite this article: \\ Natalie Yuriivna Shevchenko. Analysis of Trends in Taxation and Foreign Economic Operations with Cereal Products in Ukraine. \\ International Journal of Economics, Finance and Management Sciences. Special Issue: Taxation of Foreign Economic Operations with \\ Agricultural Products. Vol. 8, No. 5, 2020, pp. 188-193. doi: 10.11648/j.ijefm.20200805.13
}

Received: May 25, 2020; Accepted: May 27, 2020; Published: September 21, 2020

\begin{abstract}
The article is devoted to the evaluation of the current state of implementation of Ukraine's foreign economic operations using cereal crops as an example. The dynamics and the structure of cereal crops products export and import over the past decades have been studied. The facts on increase in Ukraine's export capacity exactly in the area of grain production were established. The world market of cereal crops products was considered and the share of Ukraine in world grain production, which currently does not exceed $2 \%$, was separated. The state and trends in taxation of foreign economic operations with agricultural products were estimated. The interdependence of volumes of agricultural products imports and the customs duty, excise duty and value-added tax to the State Budget during 2005-2019 was established. The decrease in imports of Ukrainian agricultural products was defined, which affects the amount of tax revenues from indirect taxes. It is also established that the gradual cancellation of customs duty on agricultural products during the transition period will lead to the drop in the State Budget revenues and domestic products competitiveness if Ukraine does not take compulsory measures to improve its market quality and stability of positions.
\end{abstract}

Keywords: Indirect Taxation, Customs Duty, Foreign Economic Activity and Operations, Agricultural Products, Customs Tariff Regulations, Cereal Crops, EU

\section{Introduction and Methods Parts}

To conduct a detailed analysis, to determine the trends and directions of Ukraine's trade policy regarding agricultural products, we will review the foreign economic situation and trade in agricultural products, in particular using cereal products as an example.

In Ukraine, a priority socio-economic role has always been ascribed to the cultivation of cereals due to the favorable natural and climatic conditions and traditionally high share of sowings. Today, more than ever, internal and, in particular, external factors of cereal farming development should provide the stable economic interest of commodity producers, as well as an appropriate level of national food security.

\section{Results and Discussion}

Analyzing the cereals export, it might be noted that for the period 2000-2007 it amounted to \$ 6.35 billion (48.2 million tonnes). At the same time, there was an annual increase, except for the lean years of 2003 and 2006-2007. If in 2001 Ukraine grew 42 million tons of cereals and oilseeds, in 2018 this indicator amounted to 85 million tons. And every year we increase export volumes of grain supplies. Over the past 5 years, Ukraine has been confidently exporting more than 40 million tonnes of grain per year. In particular, grain exports increased fivefold to almost 50 million in 2018 [1, 8] (Figure 1).

One of the main factors, which have an impact on increase in grain production and the efficiency of land use as a resource, is the right to free circulation of agricultural land.

Analyzing the structure of grain production, it might be said that the vast majority of grain exported by Ukraine are: barley-30\% on average for 8 years; wheat-54\%; maize- $15 \%$ (significant export volumes were observed in 2007, 2017 and 2018) $[2,8]$ (Figure 2). 


\section{PRODUCTION AND EXPORT EVOLUTION}

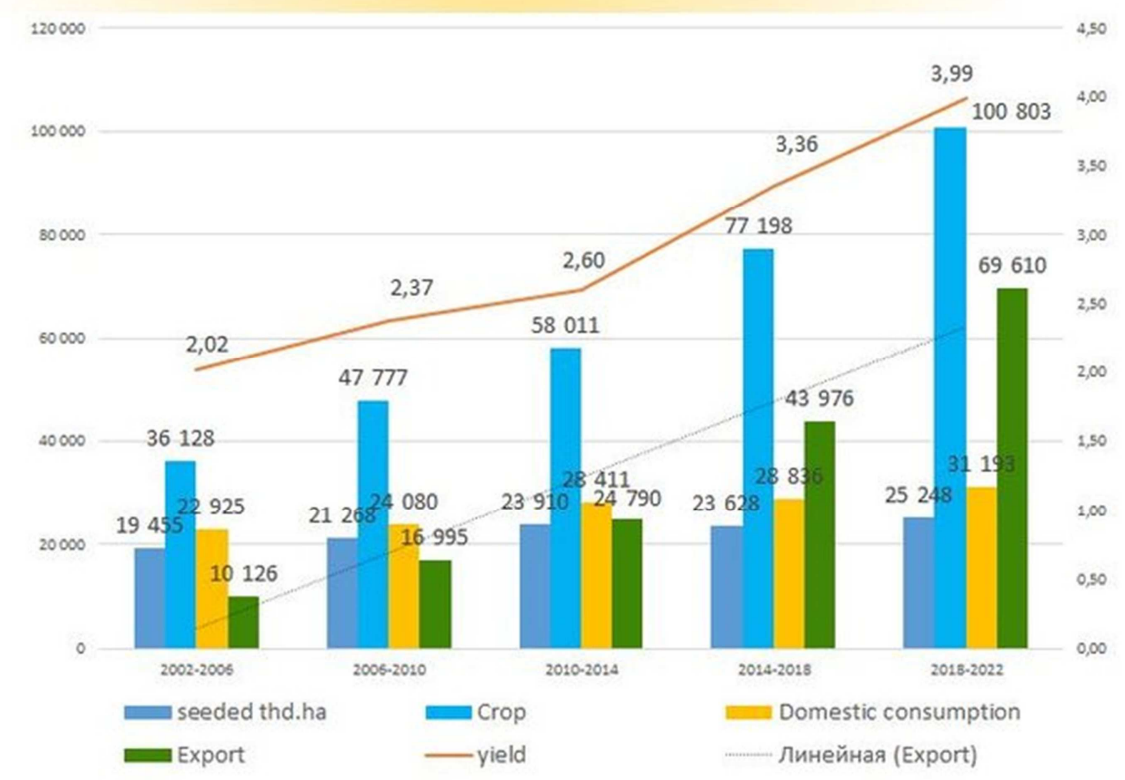

Source: [1]

Figure 1. Production and exports of cereal products during 2002-2022, (million USD).

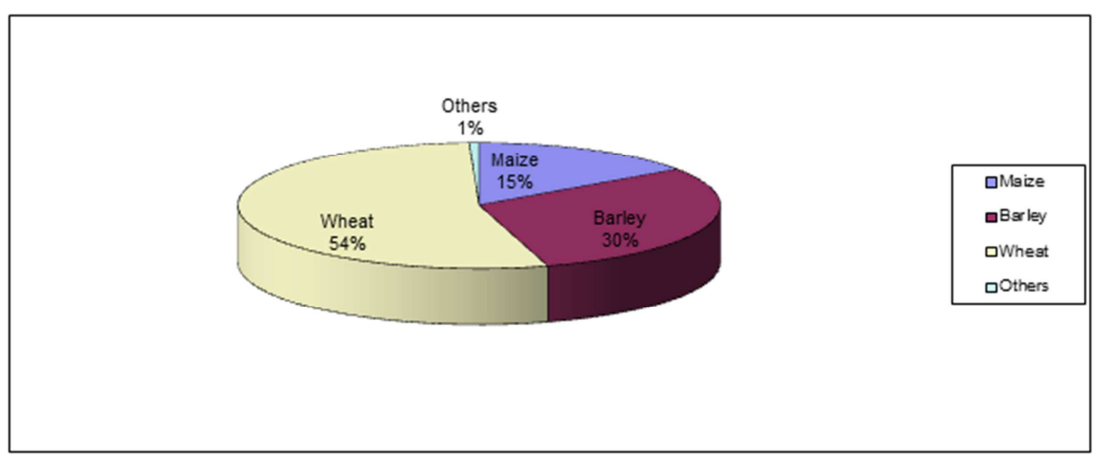

Source: $[4,6]$

Figure 2. Cereal products market during 2009-2018.

A significant leap for grain exports became 2009, during which Ukraine increased its export operations to 2.35 million tones that is by 450 thousand tonnes, or by $24 \%$, more than in the previous year. The volume of wheat and maize exports reached 1 million tonnes and 300 thousand tonnes of barley. The total volume of cereal products in 2009-2010 exceeded 22 million tonnes, including wheat9.6 million tonnes, barley-5.6 million, maize-0.6 million tonnes [3].

According to analysis of the Food and Agriculture Organisation of the United Nations and the Agricultural Market Information System data, domestic grain exports to the world market is a record high in 2018-2019 marketing period and reached about 48 million tonnes, which is almost $12 \%$ of its total global indicator (Table 1) [2, 9].

Table 1. Cereal market conjuncture in Ukraine and its impact on global trade.

\begin{tabular}{|c|c|c|c|c|c|c|}
\hline Period & Production, mln t & Offer, mln t & Consumption, mln $\mathrm{t}$ & Sales (exports) mln $t$ & Sales (imports) mln $t$ & Stocks at the end of period, $\mathrm{mln} t$ \\
\hline $2009 / 10$ & 45,6 & 54,8 & 26,9 & 20.9 & 0.14 & 7.02 \\
\hline $2010 / 11$ & 38,9 & 45,9 & 27,1 & 12,3 & 0,22 & 6,7 \\
\hline $2011 / 12$ & 56,4 & 63,1 & 29,9 & 21,8 & 0,2 & 11,5 \\
\hline $2012 / 13$ & 45,8 & 57,4 & 26,7 & 23,2 & 0,17 & 7,6 \\
\hline $2013 / 14$ & 62,8 & 70,5 & 27,2 & 32,6 & 0,21 & 10.9 \\
\hline $2014 / 15$ & 63,6 & 74,5 & 26,9 & 34,8 & 0,16 & 12,9 \\
\hline $2015 / 16$ & 59,9 & 72,8 & 24,0 & 39,6 & 0,17 & 9,4 \\
\hline
\end{tabular}




\begin{tabular}{lllllll}
\hline Period & Production, mln t & Offer, $\mathbf{m l n} \mathbf{t}$ & Consumption, mln t & Sales (exports) $\mathbf{m l n} \mathbf{t}$ & Sales (imports) $\mathbf{m l n} \mathbf{t}$ & Stocks at the end of period, mln t \\
\hline $2016 / 17$ & 65,5 & 74,9 & 23,1 & 44,6 & 0,21 & 7,3 \\
$2017 / 18$ & 60,8 & 68,1 & 22,2 & 40,0 & 0,22 & 6,0 \\
$2018 / 19$ & 69,0 & 75,0 & 21,5 & 47,9 & 0,24 & 5,8 \\
\hline
\end{tabular}

Source: [2].

This has become possible, first of all due to the formation of a high proposal of grain on the domestic market, which amounts to almost 75 million tonnes, due to its record harvest last year [4].

Totally, over the past 10 years, exports of domestic grain to the world agri-food market have more than doubled that is a significant trend for its development in the context of global agricultural integration since its accession to the WTO in 2008.

During the analyzed period, annual demand for grain in the world increased by an average of 30-50 million tones that offers a significant prospects for the domestic agricultural sector of the economy to increase its production to 100 million tonnes. It is quite realistic to achieve these indicators through the further priority development and state support of domestic agricultural science. In particular, the development of selection varieties and hybrids of cereals towards improving its yield and drought resistance, as well as improving cultivation technology, optimizing the use of mineral fertilizers and the transition of many farms to an integrated system of plant protection $[4,5,11]$.

Previously, Ukraine occupied the smallest share of the world market in cereals trade, but in 2009-2010 its share increased significantly (Figure 3 ). This is explained by the search for market outlets, increased production in recent years, and increased exports of country products.

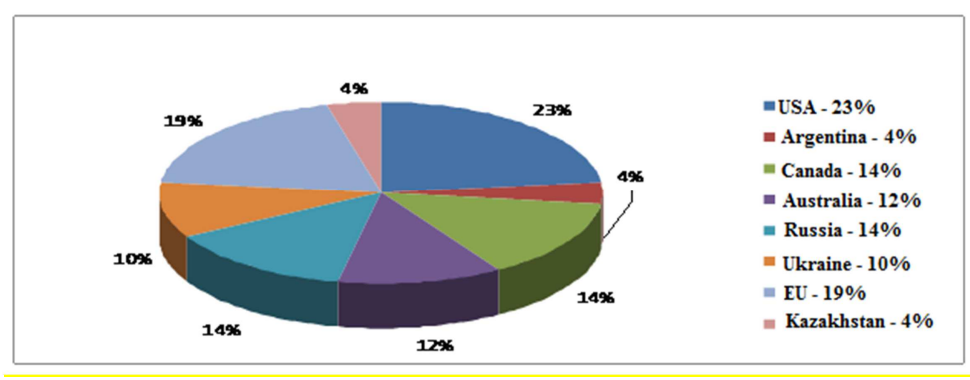

Source: $[4,12]$.

Figure 3. World cereal market during 2008-2009.

The share of Ukraine in the world grain production currently does not exceed $2 \%$, but at the same time the potential of its rise allows to increase it to at least 4-5\%. This year, despite the rather difficult weather and climate conditions, the domestic farmers managed to harvest about 62 million tonnes of grain. A record harvest has China where almost half a billion tonnes of grain were harvested in recent years, as well as in the USA, India and Russia [6] (Figure 4).
Historically, the cereal market is occupied by five major exporters (USA, EU, Canada, Australia and Argentina), its shares consist $90 \%$ of the total market. But in the early 2000s, the appearance of the Black Sea basin countries (Russia, Ukraine, and Kazakhstan) changed the balance of power. In 10 years, five traditional exporters have lost up to $20 \%$ of their market share $[6,13]$.

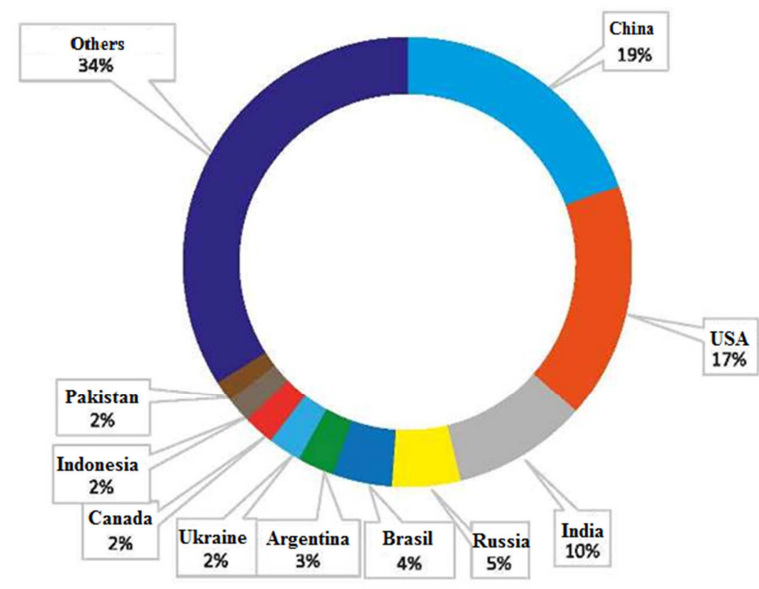

Source: [2]

Figure 4. Top 10 countries in the ranking of the world's largest grain producers during 2017-2018 marketing period (in percentages to total). 
Over the past 3 years, the most important event was the increase in production in Russia. Today, Russia is gradually becoming the second wheat exporter in the world. For 50 years, the world circulation of soft wheat varieties has increased three times, reaching 120 million tonnes of grain sold $[7,9,14]$.

Argentina, instead, has not been among the top five exporters for 2 years. In the country, from 2005 to 2009 , sown area under wheat reduced from 5 to 2.9 million hectares. Instead, they are occupied by soybeans, more profitable and politically less risky crops (market closures, export duties). The sales volumes of wheat account for $20 \%$ of the world production. The top suppliers are the USA, Canada and the EU, at the same time Russia is increasing its market share $[8,9,15]$.

The expected increase in production, including as a result of cereals exports, will significantly improve Ukraine's position in the world trade. Such a trend will certainly have a positive impact on the Ukrainian domestic market and well-being of the population. Because, already now the participants of the Ukrainian cereal market are the engine for development of the country's economy, and almost a third of the export revenue of the whole country is a merit of agro-export [1].

Since foreign economic operations have a significant impact on the tax base of the state, so the main task of the state in foreign trade area is to ensure the effective functioning of taxation of foreign economic activity.

Thus, from exports of agricultural products depends on export duties, currency incomes and increase in tax revenues (income tax and VAT), VAT refunds, subsidies, and food security costs in cases of excessive export. A similar situation is observed in the import of agricultural products and in the export and import of agricultural machinery and other industrial means of domestic and foreign proceeding [5].

Following the accession of Ukraine to the WTO and the signing of the Association Agreement between Ukraine and the $\mathrm{EU}$, the implementation of all contractual provisions has led to a decrease in the role of indirect taxes in the formation of the state budget. This is explained by the reduction of customs rates, its application on preferential terms, which somewhat narrows down the base of customs taxation (Figure 5) [7].

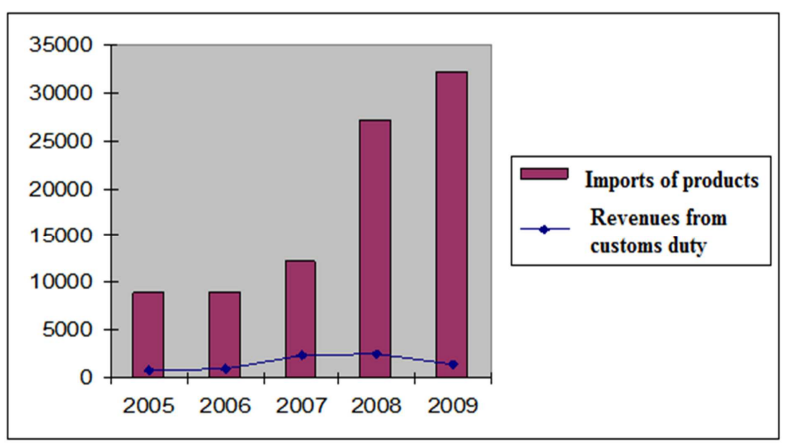

Source: $[9,10]$.

Figure 5. Interdependence of agricultural products imports volumes and amount of customs duty revenues to the State Budget, 2009, million UAH.
The implementation of combined and specific rates of import duty in 2007-2008 was aimed at avoidance of reducing the customs value of goods and deterrence from imports of low quality products by the subjects of foreign economic activity. This means, it was one of the steps to support the national commodity producer and protect the domestic market. During these years, there was a significant increase in customs revenues and imports of agricultural products [6].

In 2009-2012, ad valorem rates were the basis for import duty rates. Therefore, this explains the decrease in 2009 after the accession to the WTO in the budget revenues from such types of compulsory state payments, as customs duty (import and export) by $9 \%$, taking into account the increase in imports of products [8].

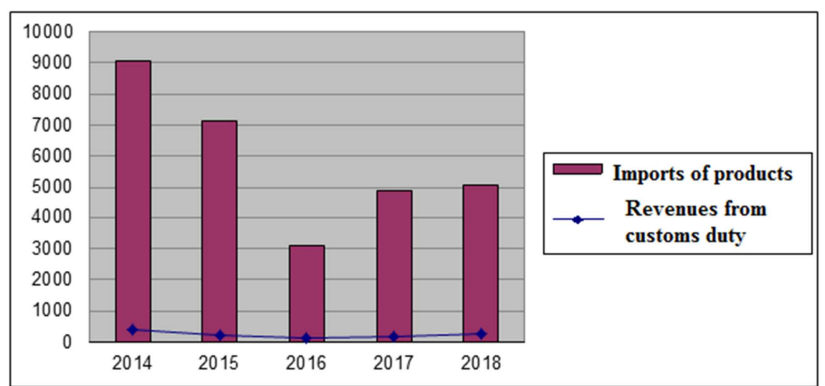

Source: $[8,9,10]$.

Figure 6. Interdependence of agricultural products imports volumes and amount of customs duty revenues to the State Budget, 2018, billion UAH.

Currently, preferential rates and partly other types are the basis for import duty rates.

Maximum import duty rates on goods of commodity groups (from 1 to 24 by Ukrainian classification of goods for foreign economic activity), which are the most sensitive for the Ukrainian market, were set for meat and food byproducts, sugar, potatoes, vegetables, butter, sunflower oil [3].

Minimum import duty rates within the $0 \%$ were set for the following food commodities: coconuts, cashews, dried grapes, unroasted coffee, green tea (unfermented) and black tea (fermented and partially fermented) for industrial processing, maize seed hybrids, soybeans, palm oil and its fractions, coconut oil, etc. [3].

The reduction of the preferential duty rates and the implementation of the transition period (2019-2025), for which the import duty rates within the Free Trade Area are reduced to $0 \%$, are explained by the real steps taken by the executive power to improve the procedure for controlling the customs value determination [5].

At the same time, after the accession of Ukraine to the WTO and the signing of the Association Agreement between Ukraine and the EU, the share of excise duty in the price of alcohol and tobacco products increases, which causes an increase in revenues from this source (Figure 7) [7]. 


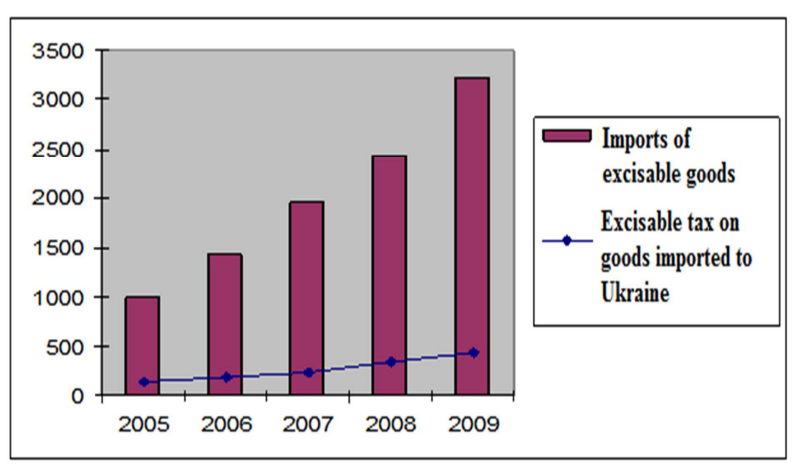

Source: $[8,10]$

Figure 7. Interdependence of excisable goods imports volumes and amount of revenues to the State Budget, 2009, million UAH.

The state of tax collection, such as excise duty, depends on a number of interrelated factors, first of all changes in rates, application of preferential conditions.

In Figure 7, the amount of excise tax revenues increase by an average of $10-15 \%$ with an increase in imports.

In 2005-2008, the alcohol products prevailed in the structure of tax revenues from imports of excisable goods and accounted for over $60 \%$ of total revenues. However, tobacco products imports have been gaining considerable momentum in recent years [10].

Taking into account the experience, there is a statement in the Ukrainian scientific opinion that in countries that are at the stage of market economy development, it is not necessary to set high rates for excise duties on goods with low elasticity of demand, which are regulated by the state, since tax pressure is regressive in nature and low price elasticity of demand does not allow to achieve the goal of deterrence from consumption [7].

In a situation, when the rate of excise duty on certain goods is high enough, with its further increase, the amount of revenues from this tax will decrease, because the volumes of imports also will decrease, and vice versa. The tax rate that provides the maximum amount of incomes is in the range from zero to the specified rate [3].

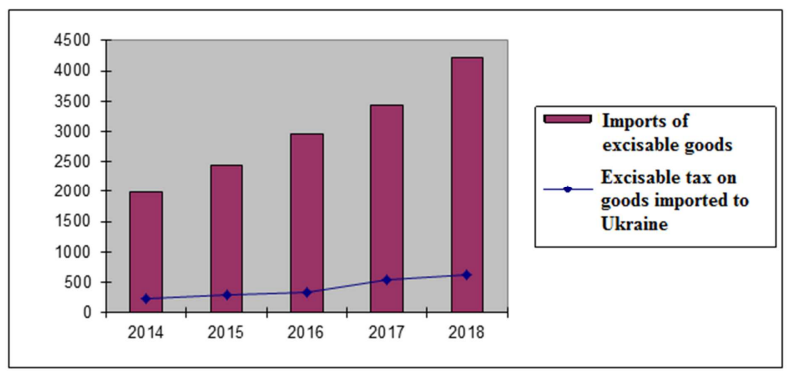

Source: $[8,10]$

Figure 8. Interdependence of excisable goods imports volumes and the amount of revenues to the State Budget, 2018, billion UAH.

In recent years, the alcohol products prevailed in the structure of tax revenues from imports of excisable goods, although in 2018 only specific rates on tobacco products have increased, and ad valorem rates have remained unchanged [3].

Attention should also be drawn to the increase in the share of VAT in amount of total tax revenues, which averaged 510\% (Figure 9).

As can be seen from the generalized data of the State Fiscal Service, shown in Figure 9, the amount of tax revenue depends on the volumes of imports, the level and base of taxation, in particular the tax rate that provides the maximum amount of incomes [10].

With the increase in imports, VAT revenues also increased: in 2007 -by $25 \%$, in 2008 -by $29 \%$ and in 2009 -by $36 \%$ compared to the previous year [10].

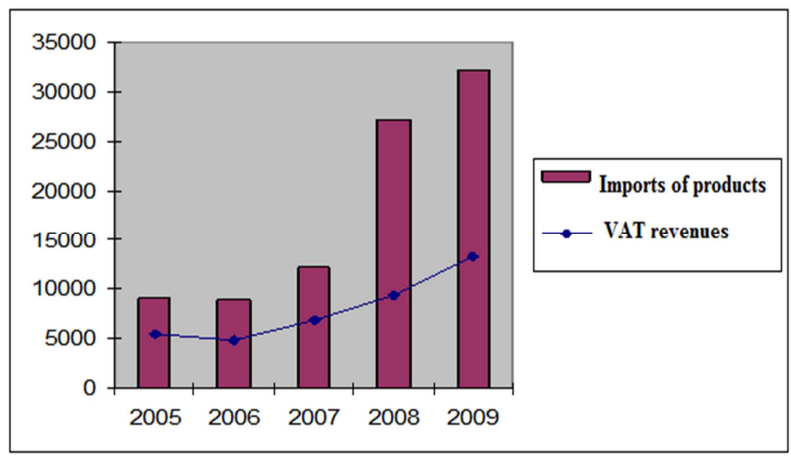

Source: $[8,10]$

Figure 9. Interdependence of agricultural products imports and VAT revenues to the State Budget, 2009, million UAH.

Therefore, work on the transformation of tax base in accordance with norms and principles of General Agreement on Tariffs and Trade/World Trade Organization runs at a satisfactory pace. One of the main tasks for the state is approximation of the Ukrainian legislation to the EU Member States' legislation in the area of trade and economic relations [8].

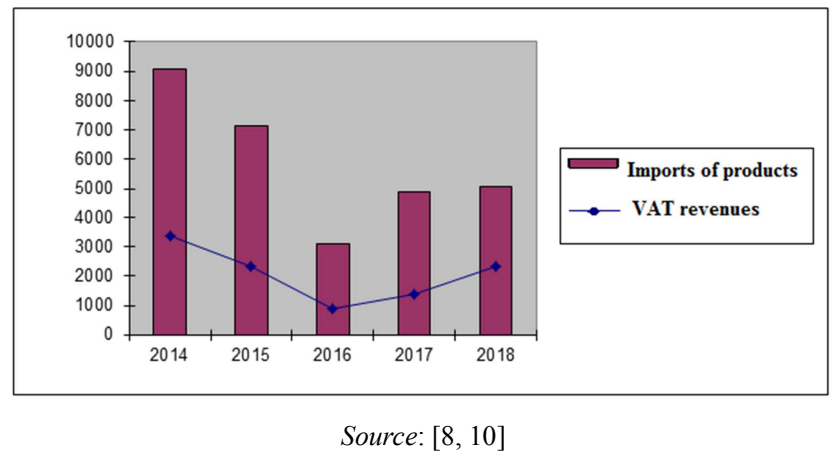

Figure 10. Interdependence of agricultural products imports and VAT revenues to the State Budget, 2018, billion UAH.

With decrease in imports, VAT revenues also reduced: in 2015 -by $25 \%$, in 2016 -by $50 \%$ compared to the previous year.

\section{Conclusion}

Analyzing the cereals exports, it might be noted that the 
country is building its export capacity in this area and trends towards its development remain positive.

For Ukraine, as an independent state, which today faces serious economic problems, the important task is to decide how to take the path of sustainable development of the economy, tax and financial system in the context of the European integration.

Ukrainian agriculture and food industry are not sufficiently integrated into the international trading system, as evidenced by the low percentage of exports and imports of agricultural and food products in gross agricultural production. In recent years, in Ukraine, the percentage of exports of agricultural and food products in gross agricultural production was $16 \%$ compared to $25 \%$ in Poland and $53 \%$ in France and Germany. Therefore, it is very important for Ukraine to improve the level of competitiveness for domestic products.

\section{References}

[1] Yaki perspektyvy zernovoho rynku Ukrainy do 2030 roku (2019). [What are the prospects for the grain market of Ukraine until 2030] Delo.ua [Online]. Available: https://delo.ua/business/jaki-perspektivi-zernovogo-rinkuukrajini-do-2030-roku-344436/.

[2] Suchasni trendy svitovoho rynku zerna (2019). [Current trends in the world grain market]. Ahrobiznes sohodni. [Online]. Available: http://agro-business.com.ua/agro/ekonomichnyihektar/item/13865-suchasni-trendy-svitovoho-rynkuzerna.html.

[3] Aktsyznyi podatok 2019 (2019). [Excise tax 2019] Holovbukh. [Online]. Available: https://www.golovbukh.ua/article/7442-aktsizniy-podatok2019.

[4] Statistics, Economics, Politics, Persons (2019). Rysky vneshnei torhovly Ukrayni [Risks of Ukraine's Foreign Trade]. [Online]. Available: https://zet.in.ua/statistika2/eksport-import/riski-vneshnej-torgovli-ukrainy/.

[5] The Common Agricultural Policy Explained. European Commission Directorate-General for Agriculture and Rural Development. [Online]. Available: http://ec.europa.eu/agriculture/publi/capexplained/cap_en.pdf.

[6] Ukrainian Agribusiness Club (2018). The main indicators of foreign trade in Ukraine. [Online]. Available: http://ucab.ua/ua/doing_agribusiness/zovnishni_rinki/osnovni _pokazniki_zovnishnoi_torgivli_ukraini.
[7] Shevchenko, N., Shulga, I., (2019) Review on Status and Trends in Taxation of Foreign Economic Operations in Ukraine. International Journal of Economics, Finance and Management Sciences, 7 (4), 103-106.

[8] Spivrobitnytstvo mizh Ukrainoiu ta Yevropeiskym Soiuzom (2019). [Cooperation between Ukraine and the European Union]. Ministerstvo rozvytku ekonomiky, torhivli ta silskoho hospodarstva Ukrainy. [Online]. Available: http://me.gov.ua/Documents/Detail?lang=uk-

UA\&id=b142801e-b932-4207-

aea9df3728dad379\&title=FaqZPitanFunktsionuvanniaVilnoiT orgivliMizhUkrainoiuTas.

[9] Zona vilnoi torhivli mizh Ukrainoiu ta ES (2019). [Free trade zone between Ukraine and the EU]. Ministerstvo rozvytku ekonomiky, torhivli ta silskoho hospodarstva Ukrainy. [Online]. Available: $\mathrm{http} / /$ me.gov.ua/Documents/List?lang=uk-UA\&id=c6fl c10b791e-4067-858009e2f2739f8e\&tag=ZonaVilnoiTorgivliMizhUkrainoiuTas.

[10] Dokhody (2019). [Revenues] Tsiny derzhavy. [Online]. Available: http://cost.ua/budget/revenue/\#1.

[11] Palchuk O., (2011) Znachennia ta rol svitovoi torhivli posluhamy $\mathrm{v}$ suchasnii ekonomitsi. [The value and role of world trade in services in the modern economy]. Doslidzhennia mizhnarodnoi ekonomiky, 1 (66), 72-78.

[12] Shevchenko, N., Lemishko, O., (2019) Review on Volumes of Foreign Economic Operations with Agricultural Products. International Journal of Economics, Finance and Management Sciences, 7 (6), 222-226.

[13] Choi, K., \& Lim, S. (2019). A reappraisal of strategic trade policies with the endogenous mode of competition under vertical structures. Journal of international trade \& economic development, 28, 11-29. doi: https://doi.org/10.1080/09638199.2018.1482948.

[14] Shevchenko, N. Yu. (2015). Osnovni chynnyky vplyvu na podatkovi nadkhodzhennia vid zovnishnoekonomichnykh operatsii z produktsiieiu ahropromyslovoho vyrobnytstva [The main factors influencing tax revenues from foreign economic operations with products of agro-industrial production]. Scientific Bulletin of NULES of Ukraine, 231, 111-116.

[15] Regulation (EC) No 450/2008 of the European Parliament and of the Council of 23 April 2008 laying down the Community Customs Code (Modernised Customs Code). (2008). Official journal of the European Union, L 145/1. Retrieved from https://publications.europa.eu/en/publication-detail//publication/3ac826c5-29db-4029-ba3d57 a52937609c/langua. 